\title{
Rural Youth Livelihood Opportunities and Impediments of Livelihood Strategy Choice in North Western Ethiopia
}

\author{
Wondale Temesgen Tedla \\ Lecturer of Sociology \\ Department of Sociology, Debre Markos University, PO box269, Debre Markos, Ethiopia
}

\begin{abstract}
In Ethiopia, attempts made by youths and local government to diversify rural youths livelihood strategies are rare at operational level. Even few project launched for youths so far with the help of nongovernmental and governmental organizations are mostly failed. The failures of these projects are mainly attributed towards the start up of the business which held an assumption of nationwide livelihood opportunities and constraints disregarding local level peculiarities. As a result youths in rural areas become victim of unemployment which forced them to take other desperate options of rural-urban and international illegal migration. Hence, this study was meant investigate local level livelihood diversification strategy opportunities and the determinants of youth livelihood strategy choice in four selected districts of East Gojjam Zone of Amhara regional state, Ethiopia. Employing cross sectional mixed research approaches, data were gathered through survey and Key informant methods from a total of 388 sample and key informant interviewee recruited from eleven Kebeles of the four districts. Data were analyzed using multinomial logistic regression, ranking methods and other descriptive statics. Findings revealed that youths in the study area are engaged in few finger counted income generating activities, among countless opportunities of on-farm off- farm and non- farm economic sectors available for rural youths. Youth are engaged not only in those livelihood strategies usually regarded as common, the strategies that they currently choose are extremely laborious and unproductive. The study further revealed that, the determinant factors behind youths participation in few laborious and less productive sectors are low educational status, lack of access to institutional credit, lack of market linkage , poor information access, and rural urban linkage, low total annual income, high dependency ratio in the family, long distance to the market center, poor road network and inaccessibility of transport facilities, and societal allocation of livelihoods on gender based criteria were found the significant determinant factor for youth livelihood strategy choice. Hence serious attention should be given for participatory approaches in identifying local level opportunities and in reducing youths' constraints for participating in diversified livelihood strategies.
\end{abstract}

Keywords: rural youth, livelihood strategy, livelihood diversification determinants, Gojjam, Ethiopia

DOI: $10.7176 / J P I D / 51-03$

Publication date: November $30^{\text {th }} 2019$

\section{Introduction}

A livelihood comprises the capabilities, assets (including both material and social resources) and activities required to make a living. A livelihood is sustainable when it can cope with and recover from stress and shocks and maintain or enhance its capabilities and assets both now and in the future, while not undermining the natural resource base (Ellis 2000, DIFDI 2008).In order to have sustainable livelihood and reduce risk and shocks individuals may follow diversified a livelihood strategy. Livelihood diversification is strategy of having diverse portfolio of activities that contributes to the sustainability of livelihoods of individuals or families (Elias 1998 cited in Khatun and Roy 2012, Porter 2012). The strategy improves family's livelihood long-run resilience in the face of risks or sudden shocks. In this respect, it works for individual and family livelihoods in same manner that it has on larger social and economic groupings. Hence, social and economic groups from small scale to large scale are advised to increase their livelihood diversity in order to promote greater flexibility and allow more possibilities for substitution between opportunities that are in decline and those that are expanding (IRP, ND, Proctor, 2014).

Poor rural livelihoods are prone to seasonality which usually caused labor smoothing and consumption smoothing and risks (Birhanu \& Getachew 2017). A livelihood approach which can give remedy to balance the gap between labor and consumption in off-peak periods by absorbing labor and generating income and which reduce risks is adopting diversified livelihood strategy. If families engaged in multiple livelihoods which do not confront similar risk profile, families livelihood in general may not faced risks. The more this comprises activities that display uncorrelated risks between them, the more successful it is at achieving this end. Furthermore, it also enables generating higher income, improving natural resource and better exploiting natural resource, improve the independent income-generating capabilities of women and in so doing, also improve the care and nutritional status of children since a high proportion of cash income in the hands of women tends to be spent on family welfare (Bryceson 1999, Bezemer, and Lerman 2002, Gordon Craig 2000, Birhanu \& Getachew 2017).

As mentioned in plethora livelihood literatures rural youth livelihood diversification strategies are very diverse. It is well recognized that in areas where youths do not have farm land access, rural non-farm and off farm 
activities have a very significant role in absorbing a growing rural labor force. It also plays, vital role in slowing rural-urban migration; in contributing to national income growth and poverty reduction and in promoting a more equitable income growth in every corner of the world (JRF 2000, Minot, et al .2006).

Regardless of plenty of diverse rural livelihood opportunities in many parts of the world including Ethiopia, the numbers of poor people in rural areas are not engaged in diversified livelihood strategies. People in developing countries are dominantly dependent on traditional agriculture which is unlikely without farming land and rainfall. However, from near the past on ward, rural societies in general and youths in particular exceed the capacity of traditional agriculture to provide sustainable livelihood opportunities (FAO 2014, Porter, 2012, Martha, 2012). Despite the astonishing rate of farming land shortage countries faced and the decline of fertility of the available land, approach of having alternative livelihood diversification doesn't bring significant change. That is the primary reason for famine and starvations, mass migration and other countless socio economic problems of that faced single livelihood dependants in most rural societies of developing countries (Haggblade, Hazell, and Reardan 2007, Martha, 2012, Bezu, Barrett, and Holden 2012).

In Ethiopia, the issue of rural youth livelihood diversification needs immediate and serious attention as the majority of population is rural youth who are either dependant on traditional agriculture or totally unemployed. According to Hiruy (2012) 80\% of youths are rural in Ethiopia. However it gets little attention by government authorities both at national and local levels. As indicated in the three national labor force survey results of CSA (2013) unemployment rate at country urban level has continuously declined from 1999 to 2005 and in 2013. To the contrary, significant rate of unemployment raise has been observed in rural areas while underemployment is obviously the manifestation of rural poor households in Ethiopia. Diversifying livelihoods on off farm and non farm sector of the economy gets attention only at policy level (Schmidt and Frew, 2016). At operational level diversification of rural youth livelihood is at lower level like most Sub Saharan countries.

Hence, rural youths are either unemployed or underemployed. As result, they become pro migration which further induced serious social economic problems in urban areas and also severe human right violation among cross border migrants that has become common social problems of the country (Hiruy, 2012, WIDE 2014 Barrett, Reardon and Webb 2001). As highlighted in literatures, livelihood diversification constraint are very diverse and complicated which needs local context investigation and analysis instead of relying solely on macro level studies and consideration of one local areas livelihood opportunities and constraint feasible for another local areas. The failure of policies on livelihood diversification at operational level in Ethiopia are mainly attributed to the dependency of local level operators at macro level studies which didn't depict the real picture of opportunities and constraints in each local context (Tesfaye 2010, Tekalign 2016).

Amhara regional state is one of the administrative regions in Ethiopia where more than $85 \%$ of the population are rural and dependant mainly on traditional agriculture. Since the region is poor in rural infrastructure and other facilities, youth are not engaged in diversified livelihood strategies (Sida2009, WIDE, 2014). East Gojjam Zone is one of the administrative regions in Amhara regional state of Ethiopia where the majority of population are still rural youth who are victim of unemployment and under employment. Local level studies on the issue are inadequate. According to (Tesfaye 2010, Sida 2009), the operation of rural livelihood diversification in the region is almost failed due to exclusive reliance on national or regional level studies and ignorance of local level opportunities and constraints. Hence this study was meant to investigate livelihood opportunities and determinants of livelihood strategy choice of rural youth of East Gojjam Zone, Amhara regional state, Ethiopia.

\section{Materials and methods}

\section{Study area}

The study was conducted in four districts of East Gojjam Zone, which is one of eleven administrative Zone of Amhara regional states in the Republic of Ethiopia. Districts were selected based on their agro ecology and food security statues of distracts in the zone. According to CSA (2013) house and population projection, of 2016 the zone has a total of 16 (sixteen) rural districts and 2,219,100 rural residents. Out of these, Enebsie sarmidir, Goncha siso Enese and Shebel Berenta districts and Sinan are sampled districts which have 33, 37, 18,16 rural kebeles, $31778,37301,26215$, 25106 rural households and 139066, 162346,114097 and 107929 total rural population respectively. The principal economic base of the community was agriculture where crop and livestock production were being treated side by side. Although average landholding of household was nearly 0.5 hectare for all districts most youth are almost land less since it is disproportionally owned by adult farmers.

\section{Data type and sources}

Since the nature of the study required both qualitative and statistical information, both qualitative and qualitative research approach were used to enhance the validity of data. Primary and secondary data were gathered from Published and unpublished literatures, reports from districts, rural youth, and development workers, Kebele administrators through documents review, survey and in-depth interview.

\section{Sample size and Sampling techniques}

The target population of the study was rural youths of the four selected districts of Eastern Gojjam Zone. According 
to Finance and economic development Office of Enebse Sar Midir, Goncha Siso Enese, and Shebel Berenta district 2016 the districts have 31, 778, 37, 301, 26, 215 and 25, 106 rural households and 139, 066, 162, 346,114, 097 and 107, 929 total rural population respectively. To get representative sample and avoid bias two stages stratified cluster sampling design was used. In the first stage, kebeles in each district were stratified according to their agro ecological zones. Then one Kebele from each agro ecological zones of the four districts were selected. Accordingly, two Kebeles from Sinan district and three Kebeles from each of Shebel Berenta, Goncha Siso Enese, and Enebsie Sar Midir districts were purposively sampled with the help of each districts' administration office employees. In the second stage, according to the number of total households in each Kebele, proportionate to size technique was applied to determine sample youths size from each Kebele. Ultimately, a total of 388 sample household heads were selected by using simple random sampling technique. The sample size of for this study, was determined using Yamane's' (1967) formula with a precision level of \pm 5 was used since the population is in its nature.

$$
\mathrm{n}=\frac{\mathrm{N}}{1+\mathrm{N}(\mathrm{e})^{2}} \text { Where }
$$

$N=$ designates total number of youths in eleven selected Kebeles.

$n=$ the sample size whom the researcher will use

$e=$ designates maximum variability or margin of error $5 \%(0.05)$.

Thus, $\mathrm{N}=13169 \mathrm{e}=0.05$

Therefore, $\mathrm{n}=\frac{13169}{1+13169(0.05)^{2}}=\frac{13169}{1+13169(0.0025)}=\frac{13169}{33.923}=388.203 \approx 388$

Statistical Package for Social Sciences (SPSS version, 20) and STATA software were used for the cleaning and structuring of data. For the quantitative data analysis various descriptive statistical tools like frequency, percentage, mean, standard deviation, ranking methods were used. Furthermore, Multinomial Logistic Regression model was fitted to identify determinants of livelihood strategy choice of rural youths in the district. The qualitative data obtained from focus group discussants were stated in narrative form concurrently with the quantitative data.

Dependent variable: As observed in different empirical studies, this variable can be expressed in terms of nominal/categorical, ratio, actual figure and form depending on the purpose of the study. The Multinomial Logistic Regression model uses censored values as dependent variable. In this study the type of livelihood diversification strategies were used as dependant variable. The strategies were categorized in to four categories as youths who engaged only on farm, On-farm + non-farm, On-farm + off-far and On-farm + off-farm + non-farm it was measured using the Simpson diversity index formula.

Independent variables: The independent variables are hypothesized to influence the level of rural youth livelihood diversification positively and negatively or which may not have significant effect on the livelihood diversification of rural youths in the study area.This includes both discreet and continuous variables listed and explained below.

Table 1 Description of variables

\begin{tabular}{|c|c|c|}
\hline Variables name & Nature & Variable value \\
\hline $\begin{array}{l}\text { Livelihood } \\
\text { diversification strategies }\end{array}$ & Categorical & $\begin{array}{l}\text { On farm only, }=1 \text { On-farm }+ \text { non-farm }=2, \text { On-farm }+ \text { off-farm=3, On- } \\
\text { farm }+ \text { off-farm }+ \text { non-farm }=4\end{array}$ \\
\hline Sex & Dummy & $1=$ male, $2=$ Female \\
\hline Age & Continues & age of youth in year \\
\hline Education & Continues & Youths 'years of formal education \\
\hline Dependency ratio & Continues & $\begin{array}{l}\text { the ratio of non labor force category member of the family plus } \\
\text { unemployed members per working member of the family members) }\end{array}$ \\
\hline Family size & Continues & number of house hold members in which youth belong \\
\hline Poor working culture & Dummy & $\mathrm{Yes}=1, \mathrm{No}=2$ \\
\hline Fear of risk & Dummy & Yes $=1$, no $=2$ \\
\hline $\begin{array}{l}\text { Laziness and } \\
\text { dependency }\end{array}$ & Dummy & $\mathrm{Yes}=1, \mathrm{No}=2$ \\
\hline Urban linkage & Dummy & $\mathrm{Yes}=1, \mathrm{No}=2$ \\
\hline Information access & Dummy & $\mathrm{Yes}=1, \mathrm{No}=2$ \\
\hline Total income & Continues & Total income of youths from all their income sources \\
\hline Credit service & Dummy & $\mathrm{Yes}=1, \mathrm{No}=2$ \\
\hline $\begin{array}{l}\text { Road and transport } \\
\text { accessibility }\end{array}$ & Dummy & $\mathrm{Yes}=1, \mathrm{No}=2$ \\
\hline $\begin{array}{l}\text { Distance to the market } \\
\text { center }\end{array}$ & Continues & Distance of youth residential home to the nearest market center in $\mathrm{km}$ \\
\hline Land ownership & Continues & area of farming land owned by youth in hectare \\
\hline
\end{tabular}




\section{Result and discussion}

The following section would cover the data findings and discussion in line with the study objectives within few thematic areas.

\subsection{Labor absorption capacity of youths' livelihood strategies}

Youth in the study area are engaged in few fingers counted income generating activities, among countless opportunities of rural youth on-farm, off-farm and non-farm economic sectors. The sampled youth reported that they had participated in one or more income generating activities, among farming, (both on farm and off farm), petty trade, social support, salary, migration labor work and construction material production selling are among the top. Out of the total youth covered in the survey research only $73(18.8 \%)$ of them had- reported that they have been participated in agriculture including farming, livestock rearing, fattening and dairy productions. This is due to land shortage, high price of land rent and lack of interest in the sector at all.

The astonishing result in the survey as indicated in table 4.1 is that social support either from members of the family who live with them or in the form of remittance is the dominant non-farm source of income benefiting more than half of the study participants $(51.8 \%)$. This also implies that more than half of rural youth in the study area are dependents on their families than living by their own toil.

It is followed by labor work 116 (29.9\%), petty trade (Such as; shop, livestock and crop trading) which accounts for 102 (26.3) and migration 57 (14.7\%), other income sources including, craft works, construction material supply, tailoring, and Areki, production 48 (12.4\%) salary (6.4\%). This finding may indicate the limited options available for youths to diversify their economy. It is widely recognized that social support is the livelihood strategy of poor in areas where livelihood diversification is very low because of various impeding factors (Adser et.al 2013). According to Adser et.al (2013), though income gained from social support or remittance is considered as livelihood strategy, it has a tendency to develop dependency syndrome among youth and to harm sustainable development of nation. As it is shown in the table, the sum of count of youth involvement in all eight (8) livelihood strategies are 522 which is 134 more than total sample youths of the study. This result indicates us only less than 134 youths are involved in more than one livelihood strategies.

Table4.1.Major Livelihood Strategies by Sampled District and Youth involvement Share

\begin{tabular}{|l|c|c|}
\hline Major livelihood activities & $\mathrm{F}$ & $\%$ \\
\hline On- farm & 23 & 5.9 \\
\hline Off- farm & 50 & 12.88 \\
\hline Petty trade & 102 & 26.3 \\
\hline Social support & 201 & 51.8 \\
\hline Others & 48 & 12.4 \\
\hline Salary & 25 & 6.4 \\
\hline Labor work & 116 & 29.9 \\
\hline Migration & 57 & 14.7 \\
\hline Total & 522 & 160.3 \\
\hline
\end{tabular}

Source: own survey2018

\subsection{Productivity Level of Youth Livelihood Strategies}

While unemployment is lack of job opportunities for population who are in labor force age category and who are actively searching for job, under employments is either partial time employment or full time employments in less productive job categories (Schmidt \& Frew 2016, Nayak 2014). As it is indicated in many livelihood studies youths are pushed away from agricultural sector and striving to generate income from non agricultural sector mostly in very laborious and less productive sector, Bezu, Barrett, Holden 2012 and FAO 2014. "According to these studies youths are employed in least paid none agricultural wage labors and salaried jobs due to lack of farming land access for agriculture and good education and training for better salaried jobs.

Findings of the current study seems to be in conformity with the study conducted by Bezu, Barrett and Holden (2012) and FAO (2014) on the issue of the correlation of rural youth with less productive livelihood activities. The average yearly productivity of sampled youths' livelihoods in the study area is shown in the table 4.2 via ratio of youth with income from each sector. It shows that other income source categories (craft works, construction material supply, tailoring and Areki production) are relatively the highest productive livelihood strategy with 23,333.33 ETB per youth followed by on farm activities, 18,874.35 ETB migration holds 13438.6 ETB, of farm contributed 13,177.8 ETB, labor work holds 13,125 ETB, petty trade is around 10,421.57 ETB, social support makes 9, 766.17 ETB, and salary contributed 7,400 ETB per youth. Although all the sectors are less productive, other income source categories, on farm sectors, migration and off farm sectors are relatively the top four productive sectors respectively, though their employment capacity is small compared to other sectors. 
Table 4.2 Youths livelihoods productivity (yearly income per youth from the sector).

\begin{tabular}{|c|c|c|c|c|}
\hline Livelihoods & Total Income share & No of youth & $\%$ & Average annual Income per youth \\
\hline On farm & 434110 & 23 & 5.9 & 18874.35. \\
\hline off- farm & 654890 & 50 & 112.88 & 13177.8 \\
\hline Petty trade & 1063000 & 102 & 26.3 & 10421.57 \\
\hline Social support & 1963000 & 201 & 51.8 & 9766.17 \\
\hline Labor work & 210000 & 16 & 4.1 & 13125 \\
\hline Salary & 185000 & 25 & 6.4 & 7400 \\
\hline Migration & 766000 & 57 & 14.7 & 13438.60 \\
\hline Others & 1120000 & 48 & 12.4 & 23333.33 \\
\hline
\end{tabular}

Source: own survey 2018

\subsection{Constraints of rural youth livelihood strategy choices}

According to Hussien \& Nelson (2004) and Ibrahim et al (2009), youths livelihood diversification is impeded by both readiness and access oriented factors. For them readiness and access-oriented youth livelihood development interventions are highly interconnected. Therefore, in order to benefit from access-oriented opportunities, many marginalized youth need youth livelihood readiness investments (from government, donor or household actors, including youth themselves). This includes formal and informal basic education, vocational and technical skills training and programs that focus on employability and the development of key cross-cutting work and life skills. Similarly, in order to convert readiness-oriented investments into viable livelihood activities, youth should have access-oriented interventions available to them. Access oriented livelihood development programming also refers to interventions that improve young people's access to market-driven products and services that can enhance their economic success such as, infrastructures, credit, land, market transport, skill, and other assets access. The success or failure of these interventions often depends on providing both kinds of programs concurrently (Start \& Johnson 2004).

As it is indicated in the above table, youth in the study area are involved in less productive activities, even more than half of sampled youths are reliant on social support as livelihood strategy. Moreover, the relative better productive livelihood strategies employed few youth compared to the less productive livelihoods. Data from survey and interviewee indicate that the youth are full of constraints to choose better productive livelihood strategy or to boost the productivity of the available livelihood strategies. According to Wilson (2008), WIDE (2014), Scoones (1998) and Adser et al. (2013), it is important to identify constraints of particular rural livelihoods in each localities in addition to the determinants of cumulative diversification strategies. Hence, this study has identified the degree of influence of some major constraints to engage in each livelihood strategy. These constraints have been found to various degree of influence across livelihood groups.

\section{Rank of major constraints to youths livelihood strategy choice}

i) Lack of Road and Transport Facilities: the table which contains rank of constraints indicated that the first constraint for petty traders and construction material producers and sellers in all Kebeles in the study area is, especially they are found far from market center and have very poor transport network. Most of the youth villages are situated far from the roads and unreachable for transport service. The youths have to cross a distance of averagely more than $15 \mathrm{~km}$ to reach the main road to avail bus or any other public transport facility. So they cannot travel and transport their product to urban centers easily. This poses a serious obstacle to bring some improvements in their livelihood strategy. Start and Johnson (2004), indicated access road and transport is a significant barrier for remote rural youth participation, in trade and urban based livelihood activities.

ii) Lack of Credit: The poor youth in the study districts have critical financial constraint to start business. They need credit facilities to develop their livelihood strategy. Due to lack of institutional credit youths are not able to undertake income-generating activity which requires some initial investment. However youths complain that even the recently initiated federal youth revolving fund is not accessible for them. Many youths could not get loans for lack of collateral requirements of the financial institutions. As a consequence, they are forced to engage in less remunerative works. It is the second most constraint for youths to engage in agriculture, trade, food and local beverage preparation and the third for craft workers as it is shown in the constraint rank table.

iii) Youth's job preference: there seems to be a wide spread selectivity among youth from a range of jobs available in their locality and skills. However, youth most of the time prefers to get employed in the formal sector rather than engaging in self-employment. According to the in-depth interview participants, public sector and employments are considered good jobs while self-employment, casual and cooperative employment are considered to be bad jobs. Unfortunately, most of those aspiring to formal sector jobs never get one because of the sector's small share in the labor man and the low educational level of youths. Constraint rank table also shows it is the third factor for youths to participate in agriculture.

iv) Access to land: one of the goals of education policy in Ethiopia is to produce educated farmers who would then 
be able to effectively adopt new agricultural technologies. However, it is completely unlikely to attain this dream without getting youth access to farm land in their areas. In the study area agriculture is the main occupation and source of income only for about $18.8 \%$ of the rural youth who get involved in the survey. Out of these, only 23 youths are working agricultural activity on their own farm though it is not sufficient for full time engagement. Nevertheless, youths are still found a way out to engage in agriculture by renting out land from holdings owned by elders who cannot plough their land by their own and also female headed households. On the other hand, youth are severely criticizing their landlessness and the rising cost of rent which is steadily moving beyond their financial capacity. The study participants also strongly argued that there is a situation when the cost of renting out the land and the market value of the products from the land become equivalent and due to this most prefer to quit the job at all. This clearly shows that rural youth who are planning to form their own nuclear family or living with their family of orientation need to acquire their own agricultural land so that they might get an opportunity to work towards increasing agricultural productivity and overall welfare via various techniques agricultural intensification, diversification, and modernization. The statistical result also clearly indicates as it is the primary factor which hinders youth's participation in agricultural activities. The studies conducted by Sosina \& Holden (2013) and Tekalign (2016) holds a similar finding with the current study and they argued that shortage or total inaccessibility of land is the deterrent factor for rural youth participation in agriculture.

v) Cultural Values: According to Lesko (2001) and Luigi (2013), Culture is not simply a large and important sector of the economy, it is a 'social software' that is badly needed to manage the complexity of contemporary regional societies and economies in all of its manifold implications. Despite this innumerable values of culture for the economy and social development unless it is commercialized and used to trigger other economic sectors, it will be a threat for development. The statistical figure from rank of constraints on the above listed livelihoods strategies and the findings from in-depth interview also confirm this fact. It indicates that cultural constraints are the first constraint for craft workers and the second and fourth constraint for construction material production and for food and local beverage preparation respectively. Participants in the in-depth interview also asserted that, in their area some economic activities are practiced by households who have low social status in the social stratification system regardless of the economic reward of the sector. Even though such activities are easily accessible for most youths, they rarely practice because of fear of social segregation and discriminations. Considerably large number of Participants said that they rather prefer to remain unemployed than involving in such informal economic sectors. According to Luigi (2013), the total indirect economic impact of culture is likely to be much bigger than the already remarkable direct one. He argued that to 'capitalize' culture it is a must to bring cultural policy at the top ranks of the policy agenda. The study finding also affirm the central negative impacts of culture for youths participation in the informal sector and the badly need of practicable cultural policy and programs in the study area.

vi) Market linkage: Poor market linkage is one of the key problems for youths to engage in handy craft production and cash crop productions. According to the participants crafts are produced either using local available row materials or by purchasing from the market. But after production there is no reliable market and customers for their product. As a result they usually face risks and get discouraged. Though there are very few number of vegetable and fruit producers in the area, they face a common problem of absence of reliable market similar to the hand craft workers. So they suffer loss for perishable products during the summer season. The issue of market linkage appears to be the fourth constraint for agriculture and craft workers and the third constraint for construction material producers. The study by Mackenzie, Mburu and Irungu (2016) and Meaza (2014), asserted that is the major determining factor for diversifying rural households income into nonfarm activities and sustaining their livelihoods. One of the informants in the kola part of Enebsie sarmidir district sad that,

“... I am working on fruit and vegetable production with my three brothers on our families farming land which covers one hectare, through irrigation. We took the water by constructing irrigation canals via digging the mountain hills. It took almost eleven months and demands annual maintenance or rebuilding after summer season. As you see there are around nineteen kinds of fruits and vegetable and coffee and chat. But the problem is almost all fruits and vegetables give product almost in the same seasons which makes harvesting and transporting it to the market a difficult task for us. As you can see there is no road and transportation service. No customer comes to here unless we took it to the market; as a result most products always remain perished in the field...'

vii) Poor information network: Poor network of information is one of the key problems among most rural youths who dropout at early schooling age. Youths in most remote Kebeles do not have knowledge of mobile phone use and net work access. As a result they do not have the chance for accurate information on alternative livelihood opportunities beyond their village and nearby residence. According to the interviewees, it is a bottle neck to youths who are engaged in petty trading for price comparison across different market centers and for youths who want to work out side of their district and Kebeles. The descriptive statistics in the table 4.3 also shows that it is the third constraint for petty traders and this result is also proved by the study of Kanji, MacGregor \& Tacoli (2005). 
According to them poor information access is the determinant factor for remote rural youths to participate in production and exchange of market based products.

viii) Lack of Training: It is widely believed that participating in vocational training increases the probability of being employed. However, the survey result of constraint rank table and the participants confirmed that access to vocational training for early school dropout youth is unthinkable. Besides this even those who have got this chance doesn't equip them with the necessary skill to undertake productive activities. Most of the Kebeles in the study district are located in highly periphery of the districts where communicating system is very poor. As a result, rural youths there have no information as well as knowledge and skill regarding modern income-generating activities. They remain stagnated on traditional activities like wage work, petty trade, charcoal and Areki production etc. In the constraint rank table it is indicated as the second constraint for craft workers and the fourth constraint for production of construction materials. Similarly, (Paul 2007) indicates lack of knowledge and training for rural youth is the leading constraint for participating, nonfarm strategies which are better productive but demands relatively advanced skill and knowledge.

ix) Lack of risk taking behavior: Being equipped with the necessary skills is important, not only to get employed in a well paying job but also for starting one's own business. The lack of entrepreneurial motivation, lack of vision/ innovation and inability to produce good business plans or feasibility studies are all part of the problem that youth are facing in starting their own businesses. It is the primary constraint for youth to work in food local beverage preparation as it is shown in the constraint rank table. Interviewee, result also admitted that youth lack confidence to start new businesses. As a result, instead of involving in business which are complementary with each other they prefer to participate common livelihood strategies of the area. They firmly believe that A necessary motivation needed for entrepreneurship is missing which is greatly contributing to the unemployment problem.

x) poor working habit and Dependency syndrome: with regard to these observations, a highly interesting finding was that laziness and dependency appear to be the defining feature of youth in the area. The statistical result on the employment capacity of youth livelihood option indicated that more than half of sampled youth are reliant of social support mainly due to laziness and dependency syndrome. Many of participants in the interview confirm this statement. The survey result of constraint rank table also shows that it is the forth and the third rank constraint for petty trade and food and local beverage preparation and sell respectively. One of the interviewee stated that:

“...Youth especially are so lazy, they don't like to work hard, they get tired quickly, and they

don't work Youth are lazy - always waiting for someone to come up with jobs, they want to be spoon fed all the time and they enjoy not doing anything. Youth don't have vision and that they don't see the opportunities available to them: "Everything is a joke to the youth, life is not serious" and they are lazy even though there are opportunities..."

Table 9- Rank of perception of constraining level of factors on rural livelihoods activities for rural livelihood groups $(\mathrm{N}=388)$

\begin{tabular}{|c|c|c|c|}
\hline Rural youth livelihoods & Constraints & Sum result & Rank \\
\hline \multirow[t]{4}{*}{ Agriculture } & Landlessness & 1178 & $1^{\text {st }}$ \\
\hline & Lack of credit & 1046 & $2^{\text {nd }}$ \\
\hline & youth interest & 1020 & $3^{\text {rd }}$ \\
\hline & Market linkage & 791 & $4^{\text {th }}$ \\
\hline \multirow{4}{*}{ Trade } & Road and transport & 1028 & $1^{\text {st }}$ \\
\hline & Lack of Credit & 1020 & $2^{\text {nd }}$ \\
\hline & Poor information network & 982 & $3^{\text {rd }}$ \\
\hline & Laziness and feeling of dependency & 858 & $4^{\text {th }}$ \\
\hline \multirow[t]{4}{*}{ Craft work } & Cultural values & 1169 & $1^{\text {st }}$ \\
\hline & Lack of skill and training & 985 & $2^{\text {nd }}$ \\
\hline & Credit & 879 & $3^{\text {rd }}$ \\
\hline & Market linkage & 847 & $4^{\text {th }}$ \\
\hline \multirow{4}{*}{$\begin{array}{l}\text { Construction material } \\
\text { production and selling }\end{array}$} & Road and transport & 1292 & $1^{\text {st }}$ \\
\hline & Cultural values & 1210 & $2^{\text {nd }}$ \\
\hline & Market linkage & 828 & $3^{\text {rd }}$ \\
\hline & Lack of skill and training & 548 & $4^{\text {th }}$ \\
\hline \multirow{4}{*}{$\begin{array}{l}\text { Food and local beverage } \\
\text { preparation }\end{array}$} & Fear of Taking Risk & 1271 & $1^{\text {st }}$ \\
\hline & Lack of credit facilities & 1230 & $2^{\text {nd }}$ \\
\hline & Laziness and feeling of dependency & 845 & $3^{\text {rd }}$ \\
\hline & Cultural values & 532 & $4^{\text {th }}$ \\
\hline
\end{tabular}

Scale: very high $=4$, high $=3$, medium $=2$, low $=1$ Source: own survey data computation of 2018 


\subsection{Multinomial logistic regression result}

The results of regression estimates are presented in Table 4.4. The adjusted R2 model chi-square and likelihood ratio test results are found reasonable. The independent variables were chosen based on the theoretical assumption and a total of sixteen independent variables were entered into the model and eleven statistically significant variables were identified in order to measure their relative importance on, rural youth livelihood strategy choice among On-farm + non-farm, On-farm + off-farm and On-farm + off-farm + non-farm with reference to on farm only livelihood strategies. This indicates that the discussion of the results focused on the impacts of the explanatory variables on youths choice among On-farm + non-farm, On-farm + off-farm and on-farm + off-farm + non-farm livelihood strategies compared to on-farm only livelihood strategy.

\section{i) Dependency ratio}

Dependency ratio was found significantly and negatively related to on-farm plus non-farm, on-farm plus off-farm, and on-farm plus non-farm plus off-farm livelihood diversification strategies equally at less than $5 \%, 10 \%$ and $5 \%$ level of significance when compared with on-farm only strategy. The negative coefficients indicated that youths with high dependency ratio are participated less in non/off-farm livelihood diversification strategies and participated more on on-farm only livelihood strategy. Keeping the other factors remain constant, high dependency ratio in the family decreased the probability of rural youths livelihood diversification into non-farm, off-farm, and in to both off-farm and non-farm activities other with reference to on farm only livelihood strategies by decrease by $3.2 \%, 6.5 \%$ and $3.3 \%$ respectively. This may forced youths to spend their working time for giving care and support for and children aged member of the family. Khatun and Roy (2012) also have found that dependency ratio be negatively related with the likelihood diversification .Contrary to these, Adugna \&Wagayehu (2012) found to have a significant and positive correlation at $10 \%$ with choice of agriculture and nonfarm strategy. According to them if there is a raise in dependency ratio, the ability to meet subsistence needs declines and the dependency problems make it necessary to diversify their income.

\section{ii) $\operatorname{Sex}$}

Being male was found to have a negative and significant relationship to on-farm plus non-farm and positive relation with on farm plus off-farm livelihood strategy choice at $10 \%$ level of significance. The coefficient indicates that male youths are more probably engaged in on-farm only and on farm plus off farm livelihood strategy than in on farm plus non-farm livelihood diversification strategy. Keeping other factors constant adopting on-farm plus nonfarm strategy for male youth decreases and on the other hand for females it increases by $49.7 \%$, and adopting on farm plus off farm strategy for male increase and for female decrease by $12.2 \%$ with reference to the on-farm only strategy. This may be due to the culture of gender division of labor in the study area; males may be pushed to agricultural activities while females are pushed to engage mainly on petty trades and other non farm activities. As participants during interview confirm traditional plaguing is a masculine task which is culturally endowed only to males. As a result males either do not have farming land or rent their farmland to male farmer for sharing of crops and cereals. Consequently young females are pushed more to the non farming activities such preparing and selling food and local drinks, and poetry work, petty trading like grain and fruits trading, and selling firewood and charcoal than males. Similarly to this result, Adugna \& Wagayehu (2012) also argued that being male has positive and significant correlation with on farm plus off farm activities levels of revealing that the male youths were able to participate agricultural activities compared to female youths.

\section{iii) Age:}

The multinomial regression result for rural youth livelihood strategy choice indicate that age and youths choice of on-farm + non-farm, on-farm + off-farm and, on-farm + off-farm + non- as livelihood strategy positively and significantly related at $5 \%$ probability. The statistical result indicates ,if other factor remain constant, as youth age increase a year the likelihood of youths choice of on-farm + non-farm, on-farm + off-farm and , on-farm + offfarm + non- as livelihood strategy increased by $4 \%, 1.3 \%$ and $3.2 \%$ respectively. This indicates multiplicity of livelihood strategies increases with advancing age. This may be due to, experience, freedom of livelihood choice and asset access increases as age increased and as a result, youths with such opportunities have more prospects of diversifying livelihood strategies. Adugna \&Wagayehu (2012) also a show in increase in age promotes youth participation on farming and non- farm activities. This is similar with (Khatun and Roy 2012) which proved the role of maturity in age as the main driving force towards livelihood diversification. Contrary to this, immaturity in age directly goes to low information access, motivation and creative capacity and resulted in low livelihood diversity in the area.

\section{iv) Educational level}

The educational level of rural youths was found to have positive correlation with youths choice of on-farm + nonfarm, on-farm + off-farm and, on-farm + off-farm + non as livelihood strategies as compare with adopting on farm only livelihood strategy. An increase in educational level significantly and positively affect youths choice of onfarm + non-farm, on-farm + off-farm and, on-farm + off-farm + non at $10 \%$ probability. The marginal effect indicates that a one level increase in their educational level will increase youths adoption of on-farm + non-farm, on-farm + off-farm and, on-farm + off-farm + non of by $0.1 \%, 2.5 \%$, and $0.1 \%$, respectively. This may be 
education enables youths to get better skill, information access, culture of flexibility and openness to new livelihood strategies, knowledge, so that, these help them to engage in diversified livelihood strategies. The finding of Khatun and Roy (2012) seems to be in line with this finding. According to them, the educational level was found to be one of the important determinants of livelihood diversification. Education is an important barrier to entry in the non-farm sector, particularly for salaried jobs and petty business. The highly educated persons diversify their livelihood options through opting for salaried jobs, self employment activities, etc than uneducated youths

\section{v) Access to institutional credit service}

Formal credit access is found to have a positive effect on youth choice of on-farm + non-farm, on-farm + off-farm and, on-farm + off-farm + non -farm, livelihood strategies at $5 \%, 10 \%$, and at 5\% Probability respectively. The multinomial regression result indicates youths access to institutional credit service increased youths choice of onfarm + non-farm, on-farm + off-farm and, on-farm + off-farm + non -farm by $8.1 \%, 6.6 \%$ and $7.5 \%$ respectively and the opposite is true. This may be due to rural youths are mostly poor in finance; it is difficult to them to start their own nonfarm activities and to engage in agriculture by renting land. Hence, access to institutional credit service may allow them to start their business. The study by Birhanu \& Getachew (2017) also has similar result. According to them, access to credit service was found to have a positive effect on the livelihood diversification. They argue since rural households are very poor in resource base, providing credit to households can improve their livelihood diversification.

\section{vi) Information access}

Access to information was found to have positively and significantly related to on-farm plus non-farm and a onfarm plus non-farm, plus off-farm livelihood strategies at $1 \%$ and $5 \%$ level of significance respectively. Holding the other factors constant, rural youth who have access to telephone communication, radio or other information source have increased the probability diversifying their livelihood on on-farm plus non-farm and a on-farm plus non-farm, plus off-farm activities by $13.2 \%$ and $16.3 \%$ respectively and reduces the probability of youths who do not have information access by the same extent compared to on farm only strategies. The possible reason could be that the access to media may improve rural youths' information on non-farm opportunities. Participants during interview also approve this finding. According to them remote rural youths who don't have information access are rarely participated in nonfarm livelihood strategies. Similarly, Yenesew, Okoyo, \& Fekadu (2015) found that households who have access to mass media have a greater likelihood to be engaged in non-farm work. They suggest that access to TV and radio enhances non-farm activities information enables the rural farm households to participate in non-farm livelihood diversification strategy.

\section{vii) Urban linkage}

Urban linkage has also found to have positive and significant correlation with on-farm plus non-farm and a onfarm plus non-farm, plus off-farm livelihood strategies at $5 \%$ and $10 \%$ probability with reference to on farm only livelihood strategy. The coefficient and marginal effect of regression result indicates having urban linkage increased the likelihood of youth participation on on-farm plus non-farm and a on-farm plus non-farm, plus offfarm strategies by $31.9 \%$ and $10.1 \%$ respectively compared to on-farm only strategies and the vice versa is true for those who don't have urban linkage keeping other factors constant. This may be that having friends/relatives in the urban area improves the rural youths' information and facilitation of conditions on nonfarm livelihood diversification opportunities. This is similar with the findings of Yenesew, Okoyo \& Fekadu (2015) as well.

viii) Access to road networks and transportation service

Access to road and transportation nearby their residence to the market center positively and significantly related to on-farm plus non-farm livelihood diversification strategy at 5\% level of significance. It increase youth participation of on-farm plus non- farm activities by $30 \%$ compared to on farm only livelihood strategy and in access to road and transport decreased the participation of youth on on-farm, plus nonfarm livelihood strategies by the same extent. These may be due to acceded to road and transport enable youth to access market centers and to engage in petty trade and exchange goods and service. Furthermore, it can also enable them to participate in casual works in urban centers. The result from participants during interview is also in line with the statistical result. According to them, youth who have access of road and transport nearby their residence are more engaged in both farming and nonfarm activities than staking on agriculture only. This is in line with (Start and Johnson, 2004) in which they proved the deterministic role of asset access especially road and transport for livelihood diversification and livelihood option opportunities.

\section{ix) Distance from the market}

Distance from the Market appears to be positively and significantly related to on-farm plus off-farm, negatively and significantly related to on farm plus none farm livelihood strategies at $1 \%$ and $5 \%$ significant levels respectively. The model result indicates that youths who are far from the market distance decreased their participation of on farm plus nonfarm activities by $6 \%$ and increased the participation of youths on off- farm activities by $0.3 \%$ with reference to on farm only livelihood strategies. The opposite is true for youths who are in nearby market centers for diversifying their livelihood off farm and nonfarm livelihoods in addition to farming. 
The possible reason could be that farness to the market center transpiration cost for participating in petty trade, urban based carousal works, and delivery of services to urban households and supplying of traditional hand crafts So that youths in remote areas favor diversifying their livelihood on farm plus off farm strategies than on none farm strategies. Similar to this, the finding of Birhanu \& Getachew (2017), indicated that distance to the market center have negative correlation with diversifying livelihood strategies. According to them households who are closer to the market centers do not have much cost to access market incentive for diversification of livelihoods.

\section{x) Total annual income:}

It was found to have positive and significant influence on households choice of on-farm plus non-farm, on-farm plus off-farm and on-farm plus non-farm plus off-farm livelihood diversification strategies at less than $5 \%$ significant level. The logistic regression result indicated that holding other factors constant, the increments in youth total income increased the participation of youths on, on-farm + non-farm, on-farm + off-farm and, onfarm + off-farm + non livelihood strategies by $51.1 \%, 58.9 \%$, and $52.1 \%$ respectively with reference to on farm only livelihood strategy. This may be due to farming youths with large total income can invest in alternative livelihood strategies, both in non-farm off farm activities. The study by Yisehak, Johan \& Janssens (2014) also found that the total annual income has positive and significant relationship with on-farm plus non-farm; and a combination of on-farm off-farm and non-farm activities. They justified this correlation as, having adequate income sources can overcome financial constraints to engage in alternative non/off-farm activities.

Table 6: Multinomial logit model estimates of households' choice of livelihood diversification strategies.

\begin{tabular}{|c|c|c|c|c|c|c|}
\hline \multirow{3}{*}{ Variables } & \multicolumn{6}{|c|}{ Youths livelihood diversification strategies } \\
\hline & \multicolumn{2}{|l|}{ On-farm + non-farm } & \multicolumn{4}{|c|}{ On-farm + off-farm On-farm + off-farm + non-farm } \\
\hline & Coef (SE.) & Marg.effct & Coef (SE.) & Marg.effct & Coef(SE.) & Marg.effct \\
\hline Sex & $-1.910 *(1.209)$ & -0.497 & $0.236^{*}(1.249)$ & 0.122 & $0.288(1.255)$ & 0.175 \\
\hline Age & $0.063 * *(0.045)$ & 0.040 & $0.039 * *(0.042)$ & 0.013 & $0.043 * *(0.029)$ & 0.032 \\
\hline Education & $0.047 *(0.540)$ & 0.001 & $0.133 *(0.520)$ & 0.025 & $0.070 *(0.391)$ & 0.001 \\
\hline Markdistan & $-0.605 * * *(0.717)$ & -0.060 & $0.216 * *(0.570)$ & -0.030 & $-0.230(0.379)$ & -0.019 \\
\hline Work cultur & $-0.136(0.343)$ & -0.021 & $-0.126(0.383)$ & -0.016 & $0.211(0.337)$ & 0.050 \\
\hline Farm Land & $-2.889(0.624)$ & -0.243 & $-2.454(0.629)$ & -0.135 & $-2.529(0.601)$ & -0.180 \\
\hline Road \&Tran & $0.225 * *(0.221)$ & 0.300 & $-0.120(0.210)$ & -0.022 & $0.018(0.126)$ & 0.001 \\
\hline Market Link & $0.277(0.242)$ & -0.001 & $0.491(0.325)$ & 0.054 & $0.470(0.266)$ & 0.059 \\
\hline Info access & $0.984 *(0.227)$ & 0.132 & $0.054(0.440)$ & 0.078 & $1.231 * *(0.685)$ & 0.163 \\
\hline Credit & $0.398 * *(0.567)$ & 0.081 & $0.531 *(0.213)$ & 0.066 & $0.254 * *(0.610)$ & 0.075 \\
\hline Urban link & $1.532 * *(0.569)$ & 0.319 & $0.279(0.260)$ & 0.103 & $1.908 *(0.490)$ & 0.101 \\
\hline Tot incom & $0.0022 * *(0.031)$ & 0.511 & $0.021 * *(0.001)$ & 0.589 & $0.022 * *(0.011)$ & 0.521 \\
\hline Dep Rario & $-0.309 * *(0.132)$ & -0.032 & $-0.332 *(0.135)$ & -0.066 & $-0.285 * *(0.125)$ & -0.033 \\
\hline Farm Size, & $0.025(0.021)$ & 0.011 & $0.029(0.015)$ & 0.013 & $-0.011(0.020)$ & -0.012 \\
\hline Fear of risk & $-0.166(1.174)$ & 0.002 & $-0.327(1.033)$ & -0.012 & $-0.457(1.014)$ & -0.051 \\
\hline Laziness & $0.314(1.320)$ & 0.101 & $-0.779(0.876)$ & -0.150 & $-0.319(0.894)$ & -0.026 \\
\hline Const & $-2.390(1.718)$ & & $-1.901(1.791)$ & & $-2.321(1.697)$ & \\
\hline
\end{tabular}

Prob $>$ chi2 $=0.000$, Pseudo R2 $=0.342 \quad$ LR chi2 $(18)=1.55$, Number of obs $=388$

$* * *, * *, *$ indicates significant at 1,5 and $10 \%$ probability levels respectively.

Source: own survey 2018

\section{Conclusions and recommendations}

The study finding revealed that, youths in the study area are engaged in few finger counted income generating activities, among countless opportunities of rural youths on-farm off- farm and non- farm economic sectors. It shows that youth at least more than half of sampled youths are reliant only on one livelihood strategy. Only few of youths are participated in two or three livelihood strategies. Among the livelihood strategies followed youths in the area agriculture (both on farm and nonfarm farm), petty trade, social support, salary, migration labor work and construction material production selling are the leading ones.

Youth are not only using only few commonly used livelihood strategies among tremendous opportunities; the strategies that they accessed or choose are also, laborious and less productive. The most interesting finding which indicated the absence of conducive environment for youths participation in productive livelihood strategies and laziness and dependency syndrome of youth is that, in the study site social support either from their families who live with them or in the form of remittance is the dominant non-farm sector which is practiced by about 201 (51.8\%) of rural youths. This indicated that more than half youths are burden of their families instead of having their own income sources and covering their expenses.

The multinomial logistic regression and constraint rank table result indicated that the existence of enormous deterring factors for youths choice of livelihood diversification strategy choice. Accordingly, low educational status, lack of institutional credit access, lack of market linkage, poor information access, and rural urban linkage, 
low total annual income, high dependency ration in the family, long distance to the market center, poor road network and inaccessibility of transport facilities, immaturity in age and societal allocation of livelihoods on gender based criteria were found the significant determinant factor for youth livelihood strategy choice.

Efforts to reduce youth livelihood diversity determinants should go beyond report and paper work. Constraint reduction measure taken by government authorities and nongovernmental organization have to be clearly identified incorporation with the community and appropriate measures have to be taken step by step instead of other blindly applying actions which are not relevant for area specific problems. Hence, rural infrastructure and institution have to be established and addressed for rural youth to diversify their livelihood strategies. Furthermore, youths should act their age and avoid relying on their families support.

\section{Conflict of interest}

Author declares no conflict of interest

\section{References}

Adser S., Line .B, Paul, C. and Spartak, K. 2013. "Livelihoods, challenges and trends: The situation for youth in Mpharane Ilunrm, South Africa. Interdisciplinary "Land Use and Natural Resource Management. Faculty of Science, University Copenhagen

Adugna, E. ,Wagayehu, B. 2012. Determinants of livelihood strategies in Wolayita, Southern Ethiopia. Agricultural research and review Vol1/5

Barrett, C.B., T. Reardon and P. Webb. 2001. Non-farm Income Diversification and Household Livelihood Strategies in Rural Africa: concept, dynamics and policy implication. In Food Policy26:315-331.

Birhanu ,Negeri \& Getachew Demissie. 2017. Livelihood Diversification: Strategies Determinants and Challenges for Pastoral And Agro-Pastoral Communities Of Bale Zone, Ethiopia. American Journal of Environmental and Geoscience, Vol 1, / 1,

Paul .B. 2007.Promoting Livelihood Opportunities For Rural Youth. Knowledge and skill for development.

Bezemer,D.J and Lerman,Z. .2002. Rural livelihood in Armenia: the center for Agricultural Economic research, The Department for Agricultural economics \&management Discussion Paper No,4.03

Bezu, S., C.B. Barrett, and S. Holden. 2012. "Does the Nonfarm Economy Offer Pathways for Upward Mobility? Evidence from a Panel Data Study in Ethiopia". World Development 40, (8): 1634-1646

Bryceson, D.F .1999. Sub-Saharan Africa betwixt and between: Rural Livelihood Practices and policies African Studies Center, working paper 43.

CSA.2013. Population projections of Ethiopia for all regions at woreda level from 2014, 2017.Addis Ababa ,Ethiopia.

CSA .2013 Key findings on the 2013 national labor force survey The federal democratic republic of Ethiopia .

DFID. 2008 . DFID's Sustainable Livelihoods Approach and its Framework

Ellis, F .2000 .Rural Livelihoods and Diversity in Developing Countries. UK: Oxford University Press.

FAO. 2014. "Promoting economic diversification and decent rural employment towards greater resilience to "food price volatility". Economic and Social Development Department .

Gordon, A. and Craig, C. 2001. Rural Nan-Farm Activities and Poverty Alleviation in Sub-Saharan Africa. Policy series 14. Chatham, UK: Natural Resources Institute. School of Law, Gondar, Ethiopia. Retrieved in July 2017 at (http//www.adapt.it).

Haggblade, S, Hazell, B and Reardan T. 2007 .Transforming the Rural Non-farm Economy, opportunities and Threats in the Developing World. John Hopkins University Press, Baltimore.

Hiruy, W. 2012. Youth Unemployment in Ethiopia: An overview. University of Gondar

Hussien, K. and Nelson, J. 2004 Sustainable Livelihoods and Livelihood Diversification. IDS working paper 69

Ibrahim H, Rahman SA, Envulus EE, Oyewole SO. 2009. Income and crop diversification among farming households in a rural area of north central Nigeria. Kandagor

International recovery platform(IRP). nd Guidance note on recovery livelihoods. Available online at www.scinzer.com -

Joseph Rowntree Foundation. (2000). Youth unemployment in rural areas. York Publishing Services Ltd.

Kanji. N., MacGregor, J., Tacoli C . 2005. Understanding market-based livelihoods in a globalizing world: combining approaches and methods. international institute for environment and development.

Khatun, D. and Roy, B.C . 2012. Rural Livelihood Diversification in West Bengal: Determinants and Constraints. Agricultural Economics Research Review Vol. 25(No.1 January-June 2012 pp 115-124, Institute of Agriculture, Visva-Bharati, Sriniketan - 731236, West Bengal Lesko, N. 2001. 'Act Your Age!' New York, Routledge Falmer.

Luigi, S ., Pier. 2013. The impact of culture on social and economic development, \& how to measure it.

Mackenzie, L. , Mburu, J. , Irungu, .P 2016 . Determinants of household choice of livelihood diversification activities in chobe district, Botswana. 
Martha, K . 2012. Employment Challenges in Ethiopia. Addis Ababa University Ethiopia

Meaza,T., W/ Gebreal. 2014. The role of non-farm activities in sustaining rural livelihood, (in the case of Enderta woreda ,tigray regional state) . A thesis for partial fulfillment of the requirement for the award of master of arts degree in development studies (regional and local development, Mekelle University college of business and economics department of management

Ministry of agriculture (MoA).2000. Addis Ababa, Ethiopia.

Minot, M., Epprecht, M., Anh, T. and Trung, L .2006. Income Diversification a Poverty in the Northern Uplands of Vietnam, International Food Policy Research Institute, Washington, DC

Nayak, K., Bimal . 2014. "Unemployment in Ethiopia: A Call for an Action. "International Journal of Management and Social Sciences Research,Vol 3, No. 4.Retrieved in Jun, 2017at (http//www.irjcjournals.org.).

Porter, C. 2012. "Shocks, Consumption and Income Diversification in Rural Ethiopia". Journal of Development Studies 48 (9): 1209-1222.

Proctor, J., Felicity. 2014. "Rural economic diversification in sub-Saharan Africa". Institute of development studies

Schmidt, E. and Frew, B. 2016 ."Rural youths and employment in Ethiopia". International food policy research institute ,working paper 98.

Scoones, I. 1998. Sustainable livelihoods, a framework for analysis, IDS working paper number 72, Brighton.

Sida.2009. Sida-Amhara Rural Development Programme 1997-2008.

Sosina, B. and Holden, T., Stein. 2013." Land Access and Youth Livelihood Opportunities in Southern Ethiopia". Center for land tenure studies working paper 11/13, Norwegian University of Life Sciences.

Start, D. and Johnson, C. 2004. Livelihood Options? The Political Economy of Access, Opportunity and Diversification UK Overseas Development Institute. Development cooperation agency .Retrieved in Julay 2017, (http://www.sida.se/publications).

Tekalign, G. 2016. "Are rural youth disengaging from agriculture? Empirical evidence from Ethiopia". Centre for Development Research, University of Bonn.

Tesfaye ,A. 2010.Contributions, opportunities and constraints of rural non-farm activities for households' livelihoods in Ethiopia: a case study from Sinan woreda, Amhara region. thesis in partial fulfillment of the Requirements for the degree of master of arts in Development studies.

WIDE .2014 "Work Creation for the Rural Youth". WIDE Discussion BriefVol5,No.3 retrieved in jun2017 at (.http//www.csae.ox ac.uk/ evstudies).

Wilson, J., David. 2008. "Youth livelihoods development Program guide". USAID/ EGAT/, Office of Education

Yenesew, S., Okoyo, N., Eric \& Fekadu, B . 2015. Determinants of livelihood diversification strategies: The case of small holder rural farm households in Deber Elias woreda, eastern Gojjam Zone, Ethiopia, African Journal of agricultural research, Vol10, No19. Retrieved in Julay2017 at (http//www.acdemicjournals.org/AJAR.

Yisehak K, Johan D, Janssens GPJ (2014). Effects of supplementing tannin rich diets with polyethylene glycol on digestibility and zoo technical performances of zebu cattle bulls (Bos indicus). J. Anim. Physiol. Anim. Nutr. 98(3):431-438. 